\title{
ASIAN VALUES DI SINGAPURA (STUDI TENTANG PERAN KONFUSIANISME DALAM KEMAJUAN POLITIK SINGAPURA)
}

\author{
ANNA YULIA HARTATI \\ Dosen Jurusan Hubungan Internasional, Fisip, Universitas Wahid Hasyim Semarang \\ Email: annayuliahartati@gmail.com
}

\begin{abstract}
This article research results that describe the role of Confucianism in Singapore's political advancement. The assumption that Asian values are eroded by Western values is not proven in Singapore. Confucianism extracted into The Shared Values evolved into a national identity and became the basis for the life of a state and society in Singapore. The role of Confucianism is vital in Singapore's political progress because of one main thing, namely to uphold the interests of the nation and state. When the interests of the nation and state are placed as a priority, the community feels as one entity that strives to maintain national unity, maintain harmony, and advance aspects of the country's life. This research uses documentary research instrument, using library research technique (library research), that is by taking data from books, articles, and internet. Design in this research use descriptive design, while the analysis using Constant Comparison (Grounded Theory Research).
\end{abstract}

Keywords: Confucianism, The Shared Values, political progress

\section{A. Pendahulun}

"The underlying philosophy is that for a society to work well, you must have the interests of the mass of people, that society takes priority over the interests of individual" (Lee Kuan Yew, Perdana Menteri Pertama Singapura). Krisis ekonomi yang melanda Asia pada tahun 1997 menjadi sebuah titik penting di mana bangsa Barat mempertanyakan kelebihan dan keberlangsungan nilai-nilai Asia. Barat berasumsi bahwa krisis ekonomi tersebut akan mengakhiri berkembangnya nilainilai Asia dan kemungkinannya bahwa nilai-nilai Barat dapat masuk ke Asia. Bagaimanakah kelanjutan nilai-nilai Asia? Apakah nilai-nilai Asia akan tergantikan dengan nilai-nilai Barat? Singapura merupakan salah satu negara anggota ASEAN yang terletak di Semenanjung Malaya. Singapura dibatasi oleh Selat Johor di sebelah utara yang memisahkannya dengan Malaysia, dan 
Selat Singapura di sebelah selatan yang membatasinya dengan Kepulauan Riau, Indonesia. Singapura merupakan negara bekas jajahan Inggris dan oleh karena itu, Singapura menggunakan bahasa Inggris sebagai bahasa mayoritasnya. Walaupun demikian, Singapura tetap menggunakan bahasa Melayu sebagai bahasa ibu atau bahasa nasionalnya. Singapura yang terletak di kawasan rumpun Melayu, kebanyakan warga negaranya malah merupakan masyarakat asing, terutama etnis Tionghoa, yang jumlahnya mencapai $42 \%$ dari jumlah total warga Singapura. Singapura menganut sistem pemerintahan republik parlementer, dimana seluruh menteri bertanggung jawab terhadap parlemen. Presiden hanya sebagai wujud simbolis, sedangkan kekuasaan berada di tangan Perdana Menteri dan Perdana Menteri memegang kedudukan mayoritas di parlemen. Dalam bidang politik, Singapura dikuasai oleh sebuah partai mayoritas yang disebut Partai Aksi Rakyat (PAP) ${ }^{1}$ PAP tidak mengizinkan adanya partai oposisi, walaupun partai tersebut dianggap bekerja secara efektif untuk kemajuan negara. Akan tetapi, dengan kinerja PAP yang otoriter tersebut, Singapura dapat berkembang menjadi

\footnotetext{
${ }^{1}$ Anon, t.t, dalam www.freedomhouse.org, diakses pada 30 Juli 2017, pukul 12.30 Wib
}

negara yang maju. Hal itu dapat dilihat dari rendahnya tingkat korupsi di Singapura. Selain itu, Singapura juga dinilai sebagai negara hunian yang nyaman karena sistem pemerintahannya yang fokus pada kesejahteraan rakyat dan penyediaan sarana yang memadai. Singapura, yang merupakan bekas jajahan Inggris, sejak awal memang sudah dikonstruksikan sebagai negara pusat ekonomi oleh penjajahnya. Inggris, pada masa itu, membangun infrastruktur yang dibutuhkan demi mencapai kemajuan Singapura. Tidak heran jika Singapura dapat menunjukkan pertumbuhan ekonomi yang pesat. Perekonomian Singapura bergantung pada ekspor dan impor, khususnya di bidang manufaktur. Kondisi politik dan keamanan yang stabil menyebabkan Singapura menjadi tujuan investasi bagi banyak negara. Untuk mendukung pertumbuhan ekonomi tersebut, Singapura juga memutuskan untuk member izin atas dibukanya tempat perjudian dan resor kasino sejak tahun 2005. Dengan segala perkembangan tersebut, Singapura disebut sebagai negara yang paling terglobalisasi dalam Indeks Globalisasi tahun 2006. Singapura memiliki pasukan militer yang paling maju di kawasan Asia Tenggara. Pasukan militer tersebut dibuat untuk mencegah adanya serangan dan 
memberikan bantuan kemanusiaan ke negara lain. Di Singapura, pria di bawah usia 18 tahun wajib mengikuti National Service selama minimal 2 tahun untuk pelatihan militer yang kemudian diarahkan sebagai serdadu cadangan. Selain itu, Singapura juga tergabung dalam FPDA (Five Power Defence Arrangements), yaitu suatu hubungan pertahanan antara Singapura, Inggris, Australia, Selandia Baru, dan Malaysia, melalui persetujuan multilateral. Walaupun Singapura memiliki pertahanan militer yang baik, Singapura juga fokus pada pertahanan non-militer karena adanya terorisme dan perang nonkonvensional. Dalam perkembangannya, Singapura juga menjalin hubungan diplomatik dengan negara-negara di ASEAN, misalnya saja Indonesia dan Malaysia. Hal itu dikarenakan adanya faktor kedekatan wilayah antara ketiga negara tersebut. Akan tetapi, kerap muncul konflik antarnegara tersebut karena adanya pertentangan politik. Selain itu, Singapura juga berhubungan dekat dengan Brunei Darussalam, dimana Singapura memiliki tempat pelatihan angkatan darat di sana. Tidak hanya di kawasan ASEAN, Singapura juga menjalin hubungan baik dengan negara lain di luar kawasan Asia Tenggara, contohnya China. Sedangkan Singapura menganggap China sebagai pasar yang baik untuk Singapura karena modernisasi yang dilakukan oleh China. Salah satu contoh kerjasama kedua negara tersebut adalah Suzhou Industrial Park yang merupakan taman industri internasional dengan teknologi tinggi. Singapura memang memiliki sejarah kerjasama yang baik dengan negara-negara lain. Akan tetapi, hal itu tidak lantas menghilangkan konflik antara Singapura dengan yang lain. Barat percaya bahwa demokrasi adalah kunci untuk kesejahteraan dan keteraturan hidup sebuah negara. Timur, khususnya Asia, memiliki keyakinan tersendiri tentang bagaimana mewujudkan kesejahteraan dan keteraturan hidup negara berdasarkan nilainilai Asia. Esai ini menggunakan metode penelitian eksplanasi dan bertujuan untuk membahas mengenai keberlangsungan nilai Asia dan peran salah satu nilai Asia, yaitu Konfusianisme, terhadap kemajuan politik Singapura.

\section{B. Rumusan Masalah}

Bagaimanakah Peran Konfusianisme dalam kemajuan politik di Singapura?

\section{Kerangka Berpikir}

Dalam Penelitian ini peneliti menggunakan Konsep Asian Values. Dalam tulisannya, "The Politics of "Asian Values", Richard Robison dengan tajam menyarikan lima ciri untuk "nilai-nilai 
Asia". ${ }^{2}$ Pertama, titik tumpu kebersamaan bukan pada negara ataupun individu, melainkan pada keluarga. Kedua, kepentingan kelompok atau komunitas lebih utama daripada kepentingan perorangan. Ketiga, keputusan politik dicapai melalui konsensus dan bukan pada konfrontasi dalam lembaga lembaga perwakilan. Keempat, harmoni hidup bersama merupakan prioritas yang dijaga dan diusahakan oleh negara yang kuat dengan prinsip-prinsip moral. Dan kelima, pembangunan serta pertumbuhan merupakan hak tiap warga serta negeri, yang hanya bisa dicapai dalam harmoni hidup bersama, di bawah pemerintahan yang kuat.

Harper, dalam tulisannya, lebih menekankan nilai-nilai Asia sebagai semacam semangat enlightenment, karena studinya pada perkembangan tradisi historiografi Asia Tenggara, baik oleh para ahli Asia Tenggara berkebangsaan asing, maupun intelektual lokal. Ia menilai, nilainilai Asia dari semangat ini, berupa pemikiran baru mengenai sikap terhadap sejarah kolonial, yang tidak harus selalu dipertentangkan dengan sikap anti-kolonial; masih berjalan. Kontinuitas nilai-nilai Asia, dalam bidang ini, sampai sekarang masih

${ }^{2}$ Richard Robison, The Politics of Asia Values, The Pacific Review vol.9, 1996 berkembang dalam skala Asia Tenggara pada umumnya (meskipun tetap ada pengecualian berdasarkan pengalaman kolonial dari masing-masing negara). Sementara bagi Thompson, nilai-nilai Asia, lebih dimaknai secara politis, dalam penyikapan Asia Tenggara vis-a-vis Individualisme Barat; bahkan ia sampai pada kesimpulan bahwa nilai-nilai Asia sebenarnya adalah pertarungan antara otoritarianisme versus demokrasi modern. ${ }^{3}$

Nilai-nilai Asia adalah sebuah ideologi politik pada tahun 1990an, yang mendefinisikan unsur-unsur masyarakat, budaya dan sejarah yang sama dengan negara-negara Asia Tenggara dan Asia Timur. Ini bertujuan untuk menggunakan kesamaan misalnya, prinsip kolektivisme untuk menyatukan orang demi kepentingan ekonomi dan sosial mereka dan untuk menciptakan identitas panAsia. Ini bertentangan dengan cita-cita Eropa yang dirasakan tentang hak universal manusia. Konsep tersebut diadvokasi oleh Mahathir Mohamad ( Perdana Menteri Malaysia selama 19812003) dan oleh Lee Kuan Yew ( Perdana Menteri Singapura , 1959-1990). Popularitas konsep tersebut memudar

\footnotetext{
${ }^{3}$ Mark R. Thomson, The Survival of Asian Values as Zivilizationsktitik, Theory and Society, vol. 29, no.5, Oktober 2000, hal. $442-448$
} 
setelah krisis keuangan Asia 1997, ketika menjadi jelas bahwa Asia tidak memiliki mekanisme kelembagaan regional yang koheren untuk menghadapi krisis tersebut. ${ }^{4}$

\section{Metodologi Penelitian}

\section{D.1. Metode dan Cara Penelitian}

Metode yang digunakan dalam penelitian ini adalah metode penelitian kualitatif. Menurut Bogdan dan Taylor, metode penelitian kualitatif ialah prosedur penelitian yang menghasilkan data deskriptif berupa kata-kata tertulis atau lisan dari orang-orang dan perilaku yang dapat diamati ${ }^{5}$

Metode Deskriptif adalah suatu metode dalam meneliti status sekelompok manusia, suatu obyek, suatu set kondisi, suatu sistem pemikiran ataupun suatu sistem pemikiran ataupun suatu kelas peristiwa pada masa sekarang. Tujuan dari penelitian deskriptif adalah untuk membuat deskripsi, gambaran atau lukisan secara sistematis, faktual, akurat mengenai faktafakta, sifat-sifat serta hubungan antar fenomena yang diselidiki. ${ }^{6}$ Ditinjau dari

\footnotetext{
${ }^{4}$ Michael D. Barr, Lee Kuan Yew and The Asian Values Debate, Asian Studies Review, vol.24, 2000

${ }^{5}$ Lexy J. Moleong, Metode Penelitian Kualitatif, Rosdakarya, bandung, 1989, hal. 23

${ }^{6}$ Moh. Natsir, Metode Penelitian, Ghalia Indonesia, Jakarta, 1988, hal.63
}

segi masalah yang diselidiki, teknik dan alat yang digunakan peneliti, serta tempat dan waktu penelitian yang dilakukan, penelitian ini masuk dalam kategori penelitian perpustakaan dan dokumenter.

Dalam metode ini peneliti berusaha untuk mendeskripsikan tentang Peran Asian Values dalam kemajuan politik di Singapura. Dengan data - data yang tersedia peneliti menganalisa tentang keadaan yang terjadi.

\section{I.D.2. Teknik Pengambilan Data}

Penelitian ini dilakukan dengan penelitian dokumen. Penelitian dokumen dimaksudkan unuk mendeskripsikan berbagai realita yang diteliti. Data diperoleh melalui sumber data sekunder. Data sekunder diperoleh dengan mengadakan evaluasi terhadap sumber, keadaan data sekundernya dan juga peneliti harus menerima limitasi-limitasi dari data tersebut. Data- data sekunder diperoleh melalui studi dokumenter, yakni melalui majalah, surat kabar, buku-buku dan sumber-sumber lain yang berhubungan dengan topik penelitian ini.

Peneliti mengumpulkan data dari perpustakaan Fisip Universitas Gadjah Mada Yogyakarta. Juga dari beberapa perpustakaan yang terdapat data yang relevan dengan penelitian ini, seperti perpustakaan wilayah Jawa Tengah dan 
Perpustakaan dari Universitas di Semarang.

\section{D.3. Teknik Analisa Data}

Analisa data dilakukan melalui interpretasi dari dokumentasi yang terkumpul, kemudian dianalisis secara deskriptif - kualitatif. Dengan mengadakan survei terhadap data yang telah ada peneliti menggali teori-teori yang telah berkembang dalam bidang ilmu yang berkepentingan. Untuk mengetahui validitas data informasi yang diperoleh diadakan Cross cheking data tersebut menunjukkan adanya reliable data yang akan dianalisa.

\section{E. Hasil dan Pembahasan}

\section{E.1. Ajaran Konfusianisme}

Konfusianisme merupakan sebuah filsafat atau cara hidup yang diajarkan oleh Konfusius pada sekitar abad ke-5 atau ke-6 SM. ${ }^{7}$ Ajaran Konfusianisme lahir di Tiongkok dan berkembang menyebar ke Asia Timur, seperti Jepang dan Korea Selatan, dan ke Asia Tenggara seperti Singapura. Konfusianisme menekankan prinsip pentingnya membina hubungan harmonis antarmanusia, seperti slogannya yang terkenal living together in harmony. Keselarasan hubungan ini diatur dalam

${ }^{7} \mathrm{Tu}$ Wei-Ming, Etika Konfusianisme Modern: Tantangan Singapura, Teraju, Jakarta, 2005, hal. 56 lima hubungan, yaitu hubungan antara penguasa dan rakyat, hubungan antara ayah dan anak, hubungan antara suami dan istri, hubungan antara saudara tua dan adik, dan hubungan antarteman. ${ }^{8}$

Dalam lima hubungan tersebut terdapat Five Constant Virtues, yaitu lima sifat yang menjadi kesatuan, yang terdiri dari Rén (kemanusiaan), Yì (kebenaran atau keadilan), Lǐ (adat yang tepat), Zhì (pengetahuan), dan Xìn (integritas). Kelima Five Constants Virtue ini didukung dengan kesetiaan dan bakti pada saudara dan orang tua. Selain itu, Konfusianisme menekankan tentang introspeksi diri (selfreflection) dan kedisiplinan (selfdiscipline). ${ }^{9}$ Konfusianime juga membahas tentang kepemimpinan melalui salah satu kutipannya yang terkenal yaitu percaya bahwa apabila niat dan keinginan kita untuk kebaikan maka rakyat juga akan menjadi baik (If your desire is for good, the people will be good).

Kon $\mathrm{Fu}$ Tse berkeyakinan bahwa reformasi masyarakat harus dimulai dengan mengembalikan setiap orang pada identitas aktualnya. Dengan ini, Kon Fu Tse bertekad untuk mengadakan reformasi masyarakat zamannya dengan memfokuskan perhatiannya pada manusia

\footnotetext{
8 ibid

${ }^{9}$ To Thi Anh, 1984, Nilai Budaya Timur dan Barat, PT Gramedia, Jakarta, hal.23
} 
itu sendiri. Maka muncullah prinsipprinsip moral dasar yang dianggap oleh Kon $\mathrm{Fu}$ Tse sebagai yang dapat membawa kedamaian, ketenangan dalam diri sendiri maupun bagi orang lain. Prinsip-prinsip moral dasar itu adalah Jen.Konfusius Kon $\mathrm{Fu}$ Tse berkata, "Jika engkau dapat mempraktekkan kelima hal ini dengan semua orang, engkau dapat disebut Manusia Jen." Tzu Chang (muridnya) bertanya apa kelima hal itu. Konfusius berkata, "kesopanan, kemurahan, kejujuran, ketekunan dan kebajikan.

Nilai-Nilai Konfusianisme di dalam istilah China, Konfusianisme menunjuk pada dua pengertian Ju Xhiao dan Ju Xhia. Dimana Ju Xhiao yang mengacu pada ajaran agama. Sedangkan Ju Xhia adalah suatu aliran atau isme dalam pengertian filsafat, budaya maupun ilmu pengetahuan. Untuk keperluan penelitian ini Konfusianisme yang dimaksud akan menitikberatkan pada penggunaan pengertian Konfusianisme dalam arti Ju Chia. Kontribusi Konfusianisme terhadap keberhasilan Singapura menjadi NIC, menjadi sesuatu yang tidak terelakkan, sebab adanya fenomena yang muncul pada negara-negara industri baru di kawasan Asia Timur seperti Hongkong, Taiwan, Korea Selatan dan termasuk Singapura telah memberikan inspirasi bagi para ahli politik dan ekonomi pembangunan Barat untuk merevisi pandangannya tentang Konfusianisme. Dimana rahasia perkembangan ekonomi yang begitu tinggi yang diperoleh oleh negara-negara industri baru harus dicari pada faktor-faktor kultural, sebab secara kultural negaranegara industri baru tersebut sama-sama memiliki latar belakang penduduk dan budaya yang sama dimana etnis Cina merupakan mayoritas di negara NICs. Dengan kultur dan penduduk yang mayoritas adalah etnis China maka budaya dari etnis China tersebut akan mempengaruhi aspek-aspek kehidupan di negara-negara NICs. Begitu pula dengan Singapura, Singapura memiliki penduduk yang mayoritas etnis China dimana budaya Konfusianisme yang melekat pada etnis China tersebut memiliki pengaruh terhadap aspek-aspek kehidupan yang ada di Singapura. Berkaitan dengan hal itu, pada bab ini akan dijelaskan tentang konsep Konfusianisme yang mempengaruhi aspekaspek kehidupan Singapura, dimana termasuk di dalamnya adalah aspek sosial politik yang berupa kekuatan nasional Singapura dengan karakter nasional dan kualitas pemerintahan sebagai elemennya

E.2. Manifestasi Konfusianisme di Singapura

Dilatarbelakangi oleh keprihatinan Singapura akan lunturnya nilai-nilai asli Asia yang mulai tergantikan oleh nilai- 
nilai Barat, seperti pergantian komunitarianisme menjadi individualisme, Deputi Pertama Perdana Menteri Goh Chok Tong dalam pidatonya pada 28 Oktober 1988 mengusulkan untuk membentuk ideologi nasional yang terdiri dari nilai-nilai nasional Singapura. Pada tahun 1991, pemerintah Singapura menetapkan The Shared Values yang merupakan lima buah nilai nasional Singapura. The Shared Values mengandung perspektif dan nilai-nilai Konfusianisme dan menjadi identitas sekaligus ideologi nasional Singapura yang disusun dengan mempertimbangkan aspek multikulturalisme Singapura. Kelima nilai yang ada dalam The Shared Values $\operatorname{adalah}^{10}$ :

1. Bangsa sebelum komunitas dan masyarakat di atas diri individu

2. Keluarga sebagai unit masyarakat yang utama dan mendasar

3. Dukungan komunitas dan penghormatan/penghargaan untuk individu

4. Konsensus, bukan konflik

5. Harmoni ras dan agama

The Shared Values mencerminkan nilai-nilai Konfusianisme. Pertama, The

${ }^{10}$ Singapore National Library Board, 2016, https://www.gov.sg/, diakses 30 Juli 2017, pukul 20.00 Wib
Shared Values mencerminkan adanya hierarki dalam masyarakat, yaitu pertamatama masyarakat harus memprioritaskan bangsa dan negara, lalu baru kepentingan individu termasuk kepentingan keluarga. Kedua, The Shared Values juga menekankan pentingnya hubungan harmonis dalam keluarga dan juga keharmonisan ras dan agama, seperti konsep living in harmony. Ketiga, sesuai dengan prinsip menjunjung keharmonisan dalam ajaran Konfusianisme, The Shared Values mendukung konsensus dan menghindari konflik. Keempat, dukungan komunitas juga mencerminkan nilai-nilai Konfusianisme. Dukungan komunitas berarti memberi perhatian khusus pada orang-orang yang kurang beruntung dengan kegiatan sukarela sosial. Hal ini sesuai dengan konsep Rén (kemanusiaan) dalam ajaran Konfusianisme.

Konsep Konfusianisme yang dimaksud adalah etik Konfusianisme dan konsep di empat penjuru samudera adalah saudara yang mendukung dari karakter nasional dan konsep lima hubungan manusia/five human relationship yang mendukung dari kualitas pemerintahan Singapura.

Konsep Pertama, Etik Konfusianisme Dalam etnik Konfusianisme, ajaran yang paling 
mendalam dari Kŏngžr dengan demikian terletak pada tekanannya untuk membangun diri atau pemberadaban diri (self-cultivation), keteladanan moral serta kemampuan untuk membuat keputusan yang terlatih baik, ketimbang pengetahuan akan hukum-hukum alam. Refleksinya, konsep konfusianisme dalam etik konfusianisme adalah sikap-sikap pembenahan dan pembentukan kualitas diri. Seperti etos kerja yang giat, rajin dan serius tunduk terhadap otoritas yang lebih tinggi, menghormati orang tua, etos kerja yang giat, rajin dan serius, selalu mencari konsensus dan keharmonisan dan menekankan pada ketertiban dan stabilitas.

Selanjutnya akan kita lihat bagaimana kontribusi dari etik Konfusianisme terhadap perkembangan negara Singapura, sehingga Singapura termasuk kategori negara-negara industri baru/Newly Industrialized Countries (NICs). Di dalam etik Konfusianisme terhadap sikap hidup yang selalu mencari keharmonisan dan menekankan pada ketertiban dan stabilitas. Konsep ini mewarnai aspek-aspek kehidupan di Singapura termasuk aspek sosial dan politik, terutama pada masa pemerintahan yang dipimpin oleh Perdana Menteri Lee Kuan Yew. Keharmonisan, kestabilan dan ketertiban menurut pemerintah Singapura amat diperlukan dalam menciptakan kondisi negara yang aman. Dimana dengan kondisi negara yang aman dan stabil, maka akan membuat iklim ekonomi di dalam negeri Singapura dapat tercipta dengan baik. Hal ini dapat dibuktikan dengan melihat cara Lee Kuan Yew dalam menangani/mengatur negaranya. Untuk menciptakan kondisi negara Singapura yang stabil dan aman yang dapat mendukung iklim ekonomi yang baik dan mendukung proses pembangunan, maka pemerintah Singapura menerapkan disiplin, baik itu disiplin politik maupun disiplin sosial. Dan tantangan bagi Lee dalam menerapkan kebijakannya itu adalah bagaimana menyeimbangkan antara yang menurutnya sangat diperlukan yaitu disiplin sosial dan politik dengan kebebasan yang diinginkan oleh rakyat Singapura: "Lee challage was to strike a balance between what he considered necessary, namely tight social and political discipline, and what "his" people, who growing more affluent and better-eduated every year, might have preferred, namely more freedom". Penerapan disiplin politik dimaksudkan agar kondisi politik dalam negeri Singapura stabil dan tidak dalam kondisi konflik akan tetapi dalam kondisi yang harmanis. Untuk itu pemerintah Singapura mempraktekkan sistem satu partai dominan walaupun secara teknik Singapura menggunakan sistem multipartai. 
Mengenai hal tersebut Lee Kuan Yew sebagai Perdana Menteri Singapura mempunyai visi/pandangan yaitu, dia (Lee) lebih senang sistem satu partai dominan karena Lee beranggapan dengan sistem tersebut akan membawa keamanan dan kemakmuran, dan menurut Lee pula bahwa partai oposisi yang kuat bukan sesuatu yang penting dalam demokrasi dan bahkan partai oposisi akan menciptakan ketidakharmonisan. Dan pandangan Lee tersebut sering dijelas-jelaskannya kepada rakyat Singapura: "Lee likes to expound on his vision of a one party government that brings peace and prosperity. He argues that strong oposisition parties are not essential to democracy, that infact they would only promote disharmony. This is a profoundly Confucian Veiw”.

Selain mempraktekkan sistem satu partai dominan pemerintah Singapura juga menegakkan disiplin politiknya dengan memberantas korupsi. Hal ini juga untuk menciptakan kestabilan politik dalam negeri yang dapat mendukung iklim ekonomi yang kondusif bagi proses pembangunan. Dan dalam rangka untuk mencegah dan memerangi korupsi, di Singapura ada The Corrupt Practice Investigation Bureau (CPIB), dimana CPIB ini bertanggung jawab secara langsung pada Perdana Menteri. Dan hasilnya adalah Singapura dikenal sebagai negara yang rendah tingkat korupsinya: "Since 1957 corruption has steadly increased in Malaysia and also the rest of The Asean Countries with exception of Singapore”.

Kebijakan pemerintah mengenai disiplin sosial tersebut mengikat kehidupan rakyat Singapura, dimana segala sesuatunya penuh dengan aturan. Dari mulai dilarang meludah sembarangan, dilarang merokok di tempat umum, dilarang menghentikan bis di sembarang tempat (harus di halte) dan lain-lain, jika semua itu dilanggar maka konsekwensinya adalah "fine" (denda); (You can be fined for eating on subway, smoking in restaurant, failling to flush a urinal). Dengan memiliki peraturan-peraturan yang ketat dan sanksi hukum yang relatif berat, maka hasilnya memang Singapura menjadi terkenal negara yang serba teratur. Keteraturan ini merupakan hasil dari kebijakan yang diterapkan oleh pemerintah Singapura dengan menerapkan disiplin sosial politik dan membuat kondisi Singapura menjadi relatif stabil. Dan kebijakan ekonomi open door for foreign investment juga berjalan dengan baik sebab didukung dengan kondisi politik sosial yang stabil dan minimnya korupsi, serta kondisi masyarakat yang bersiplin 
dan teratur. Dengan situasi kondisi yang aman dan stabil itulah Singapura menawarkan kepada investor untuk menanamkan modalnya di Singapura; "Singapore offers them (foreign investor) inexpensive labor and a favorable business environment of political stability and minimal corruption".

Hasilnya adalah antara tahun 1960 sampai 1970 TNC (Transnational Corporation) datang ke Singapura dengan beberapa alasan diantaranya karena kondisi dalam negeri Singapura yang stabil: "During 1960s and 1970s TNC (Transnational Corporation came to Singapore in response to political stability". Dalam Etika Konfusianisme terdapat definisi tunduk terhadap otoritas yang lebih tinggi. Artinya dalam hubungan antara rakyat dengan pemerintahnya, rakyat dituntut untuk patuh terhadap aturan-aturan pemerintah yang berlaku. Dan dalam rangka menciptakan stabilitas di Singapura pemerintah mengeluarkakn ebijakan-kebijakan yang keras untuk membuat Singapura menjadi negara yang tertib dan teratur. Pelanggaran terhadap peraturan mempunyai konsekuensi hukum terhadap pelanggarnya. Peraturanperaturan yang keras, dengan saksi yang tanpa pandang bulu, diciptakan oleh pemerintah Singapura untuk membangun suatu masyarakat yang modern yang berdisiplin. Dan itu berarti bahwa kebebasan warga Singapura menjadi terbatas. Mengenai hal itu Lee Kuan Yew memiliki pandangan konfusianisme tentang kebebasan individu; "From Lee's Confucian perspective, emphasis on individual freedoms in The West puts lawabiding citizens at the mercy of criminals. In Singapore there is discipline and respect for those in authority, and people not afraid to venture out on the streets at night."

Konsep Kedua, lima Hubungan Antar Manusia Sebuah konsep dari ajaran Konfusianisme yang mendukung dengan kualitas pemerintah Singapura (The Quality of Government) adalah konsep yang dinamakan five human relationships. Five Human Relationships yaitu ajaran Konfusianisme mengenai bagaimana hubungan antara pemerintah dengan rakyatnya yaitu bagaimana rakyat dalam bersikat terhadap pemerintah serta bagaimana pemerintah bersikap terhadap rakyatnya. Five Human Relationships yaitu: 1. Hubungan antara Raja dan Menteri, 2. Bapak dan anak, 3. Suami dan istri, 4. Kakak dan adik, 5. Teman. Jika lima hubungan itu digambarkan sebagai hubungan antar aparat pemerintah dan aparat pemerintah dengan rakyatnya; yaitu seorang pemimpin (perdana menteri) harus bertindak sebagai pemimpin dan para 
ASIAN VALUES DI SINGAPURA

(STUDI TENTANG PERAN KONFUSIANISME

DALAM KEMAJUAN POLITIK SINGAPURA)

pembantu pemimpin (menteri-menteri) itu juga harus bertindak sesuai dengan jabatannya. Artinya jika seorang pemimpin mengeksploitisir/menipu rakyatnya maka kemungkinan besar para pembantunya juga akan berbuat hal yang sama dan nantinya akan timbul kekacauan dan seorang pemimpin juga harus bisa berlaku sebagai ayah yang tidak boleh mengabaikan tugasnya agar dapat ditaati oleh anakanaknya (rakyatnya).

Konsep Ketiga, Empat Penjuru Samudera adalah Saudara. Diatas telah dijelaskan, salah satu lima sikap yang terutama dalam Jen yaitu ketekunan. “...Jika engkau tekun, engkau akan memperoleh hasilnya“. Ketika etik konfusianisme fokus terhadap pengembangan diri manusia, dan lima hubungan antar manusia pada sistem sosial, kini empat penjuru samudera adalah saudara ini menerapkan kepada individu untuk melakukan segala hal dengan ketekunan dan memberikan bentuk nilai atau hasil.

Konsep ini di kaitkan pada masyarakat konfusianisme untuk selalu tekun dan serius guna mencapai hasil kerja yang sempurna, termasuk dalam bidang bisnis sebagai pondasi keberhasilan Singapura dalam bidang ekonomi. kesuksesan orangorang etnis Cina yang dalam bidang bisnis.
Etnis Cina dimana kita ketahui sebelumnya merupakan mayoritas di Singapura sehingga kemampuan berdagang juga melekat pada orang-orang Singapura; "Trading is a Skill easily mastered by the Chinese. Or at least those Chinese who emigrated to Southeast Asia. Therefore, Singapore with aits large ethnic Chinese population is well provisioned."

Keahlian orang-orang etnis China di Singapura dalam hal perdagangan dapat dibuktikan dengan data perusahaanperusahaan yang terdaftar dalam bursa saham Singapura $81 \%$ nya adalah milik orang-orang etnis China. Salah satu keahlian dari enis China dalam berdagang adalah kemampuan mereka membentuk jaringan dalam berbisnis. Keahlian dalam berbisnis etnis China dengan membentuk jaringan sejalan dengan konsep yang ada dalam konfusianisme. Dalam konfusianisme terdapat konsep tentang "Di Empat Penjuru Samudera adalah Saudara" (Lun Gi XII:5) dan ini juga merupakan kunci keberhasilan orang-orang Asia Timur (termasuk Singapura) dalam membina dunia bisnis mereka. Karena dengan konsep tersebut orang-orang etnis Cina mengembangkan usahanya melalui jaringan bisnis dimana itu merupakan keahlian dalam berdagang. Jaringanjaringan bisnis yang dimiliki pengusaha 
etnis Cina menyebar dan menembus batasbatas negeri. Banyak perusahaan keluarga etnis Cina skala besar yang menjadi transnasional. Misalnya, The Overseas Union Bank, The United Overseas Bank, Tat Lee Bank, dan kelompok-kelompok OECB Bank, yang semuanya dimiliki oleh keluarga, telah membangun bisnis di Malaysia. Kelompok Hong Leong di Malaysia merupakan kelompok yang tumbuh dari sebuah kelompok perusahaan Singapura. Perusahaan miliknya berkembang, tidak hanya bergerak dibidang alat-alat perkebunan tetapi juga dibidang properti, bisnis bidang kontraktor, perhotelan, semen, barang-barang baja. Kerajaan keluarga Kwek tidak terbatas di Singapura tetapi elompok Hong Leong berhasil mengembangkan usahanya di luar Singapura. Konsep Di Empat Penjuru Samudera adalah Saudara ini dapat dilihat pada keluarga Kwek yang tergabung dalam Hong Leong ketika mengembangkan usahanya, dimana ketika mengembangkan usahanya di Malaysia. Konsep tentang di Empat Penjuru Samudera adalah Saudara merupakan konsep tentang pembentukkan jaringan bisnis agar lebih mengembangkan usahanya keluar dari wilayah usaha yang dibentuknya. Konsep ini telah diterapkan oleh pengusaha-pengusaha etnis Cina pada umumnya termasuk etnis Cina di Singapura. Jaringan bisnis pengusaha etnis
China Singapura tidak hanya pada negara tetangganya (Malaysia) saja akan tetapi jaringan yang dibentuk oleh pengusaha entis China juga sampai di Hongkong, Taiwan, Filipina, dan RRC bahkan sampai ke negara Inggris. Jaringan bisnis yang dibangun oleh pengusaha etnis China Singapura telah membuktikan bahwa konfusianisme juga mempengaruhi kehidupan bisnis orang-orang etnis China Singapura sehingga hal itu juga menjadi salah satu keahlian mereka dalam dunia perdagangan. Dan pada akhirnya konsep tentang Di Empat Penjuru Samudera adalah Saudara yang diimplementasikan oleh para pengusaha etnis Cina di Singapura dengan membentuk jaringan bisnis memberikan kontribusi pada terbentuknya karakter nasional dimana karakter nasional Singapura merupakan salah satu unsur kekuatan nasional Singapura yang menjadi salah satu faktor dari keberhasilan Singapura menjadi negara NIC.

Perkembangan

Konfusianisme Implementasi ajaran Konfusius telah memberikan sumbangan positif bagi pertumbuhan ekonomi yang cepat dalam rangka proses modernisasi di Singapura. Secara garis besar, ajaran Konfusius yang diimplementasikan dalam kehidupan sosial di Singapura telah menopang terjadinya pertumbuhan ekonomi Singapura yang 
cepat. Ajaran Konfusius yang dilihat sebagai faktor pertumbuhan ekonomi yang cepat di Singapura adalah ajaran mengenai kepatuhan dan kesetiaan, pemahaman bahwa negara adalah agen moral yang aktif dalam pembangunan masyarakat, penghormatan atas status dan hierarki, penekanan pada pengembangan diri dan pendidikan, dan perhatian terhadap harmoni sosial. Berkembangya waktu dan modernisasi, ideologi konfusiansme mengalami perkembangan menjadi neo konfusianisme. Neo konfusianisme merupakan penggabungan antara nilai-nilai konfusianisme, Daoisme dan Budhisme. Yaitu dimana konfusianisme mengajarkn penyelaraskan hubungan antar manusia, Daoisme memberikan nilai perlunya hubungan manusia dengan alam, serta Budhisme yang menganjurkan penyelarasan hubungan antara manusia dengan sang pencipta. Ini bermula dari perdebatan antara Men zi dan Kong Zi yang turut menyelaraskan hubungan dari berbagai aspek. Selain hubungan antar manusia, Men $\mathrm{Zi}$ mencoba menitikberatkan penyelarasan hubungan manusia dengan alam. Neo-Konfusianisme adalah bentuk Konfusianisme yang terutama dikembangkan selama Dinasti Song, tetapi aliran ini mulai nampak ke permukaan sudah sejak zaman dinasti
Tang lewat Han $\mathrm{Yu}$ dan $\mathrm{Li}$ ao. Neo konfusianisme menekankan konsep Etik Konfusianisme pada pengembangan diri melalui pendidikan.

Adapun visi pendidikan di Negara Singapura adalah "First World Economy, World Class Home" dengan menekankan pentingnya sisitem pendidikan yang berkualitas tinggi. Visi di bidang pendidikan bukan semata-mata sebagai sarana pengembangan sumber daya manusia namun juga menjadi sumber keuangan negara. Untuk mencapai visi tersebut pemerintah Singapura membentuk suatu lembaga yaitu Singapore Education. Singapore Education adalah suatu inisiatif multi-lembaga yang didirikan oleh Pemerintah Singapura untuk mengembangkan dan mempromosikan Singapura sebagai pusat pendidikan berkualitas dan membantu siswa internasional mengambil keputusan dalam hal belajar di Singapura.

Dalam kinerjanya lembaga ini dibantu oleh beberapa lemabaga lain yang mempunyai tugas berbeda sesuai keahliannya masing-masing. adapun lembaga tersebut antara lain: Singapore Tourism Board (STB) - Education Services Division $\square$ Lembaga ini mempunyai peran untuk mempromosikan Singapore Education di luar negri, sehingga nantinya 
Negara lain akan mengetahui pendidikan di Singapura itu seperti apa. Jika dirasa memang bagus, maka mungkin saja Negara-negara yang lain akan tertarik dan melakukan kerjasama dengan Singapura. Dalam lemabaga ini terdapat tiga departemen yang masing-masing mempunyai fokus pelayanan pendidikan yang berbeda yaiu: Pengembangan pasar dan Industri Pendidikan Penyelenggaraan seminar dan pameran pendidikan $\square$ Pelatihan bagi para konsultan pendidikan Pengembangan media internasional 2 . Strategi pemasaran industry pendidikan Lembagai ini mempunyai tugas untuk menarik berbagai institusi pendidikan terkenal dari luar negeri untuk membuka kampusnya di Singapura. Sehingga masyarakat Singapura tidak usah pergi jauh-jauh menimba ilmu di perguruan tinggi terkenal di luar negri karena di negerinya sendiri sudah ada perguruan tinggi tersebut,Mengontrol kualitas dari organisasi pendidikan swasta di Singapura. Sehingga apabila terdapat organisasi pendidikan yang kualitasnya menurun dapat diketahui secara langsung dan nantinya dapat diperbaiki.

\section{E.4. The Shared Values dan Kemajuan}

\section{Politik Singapura}

Kemajuan politik dapat diartikan dalam sebelas arti, salah satunya adalah mencakup kemajuan sosial. Pye dalam bukunya beranggapan bahwa kemajuan politik merupakan sebuah kesatuan aspek proses kemajuan sosial yang multidimensi. Dalam kata lain, kemajuan politik tidak hanya mencakup aspek politik, tetapi juga aspek-aspek ekonomi dan sosial. Mengacu pada definisi ini, maka kemajuan politik sebuah negara juga melibatkan kemajuan ekonomi dan kemajuan sosial. ${ }^{11}$

Deklarasi Kopenhagen tentang kemajuan sosial menyatakan bahwa perkembangan sosial harus membentuk komunitas yang solid dan egaliter sehingga tercipta perdamaian, kesejahteraan, dan keteraturan sosial. Perkembangan sosial terwujud dengan pemenuhan kebutuhan dasar manusia ${ }^{12}$. The Shared Values terbukti berkontribusi pada kesuksesan politik dan sosial negara Singapura. Singapura percaya bahwa untuk menjadi negara maju dibutuhkan Sumber Daya Manusia (SDM) yang unggul. SDM yang unggul harus memiliki karakter yang baik. Hal inilah yang mendasari pendidikan karakter di Singapura ditanamkan sejak

${ }^{11}$ Pye, L. (1996). Aspects of Political Development: An Analytic Study. Boston, MA: Little Brown, hal. 233

${ }^{12}$ Homfeldt, H.G. and Reutlinger, C. (2008). Social Development. Social Work and Society International Online Journal, 6(2). Retrieved from http://www.socwork.net/sws/article/view/7 0/372,diakses 22 Juli 2017, pukul 12.00 $\underline{\text { Wib }}$ 
ASIAN VALUES DI SINGAPURA

(STUDI TENTANG PERAN KONFUSIANISME

DALAM KEMAJUAN POLITIK SINGAPURA)

masa sekolah. Singapura juga optimis bahwa pendidikan merupakan kebutuhan dasar dan sarana yang penting dalam mendidik karakter dan mencerdaskan generasi bangsa. Oleh karena itu, untuk membentuk karakter masyarakat Singapura, The Shared Values diajarkan di sekolah khususnya melalui mata pelajaran Pendidikan Kewarganegaraan dan Pendidikan Moral. ${ }^{13}$ Tidak hanya itu, penanaman nilai-nilai yang ada dalam The Shared Values juga dilakukan oleh orang tua.

The Shared Values menekankan pentingnya hubungan keluarga yang harmonis, termasuk seperti mendidik dan merawat anak dengan baik serta menghormati orang tua. Peran keluarga sangat penting dalam menanamkan nilainilai moral yang mendukung anak memiliki karakter yang baik. Keharmonisan dalam keluarga mendukung penanaman nilai-nilai ini. Sebaliknya, keluarga yang tidak harmonis, akan menghambat penanaman nilai moral sehingga menghambat pembentukan karakter anak.

Penanaman nilai-nilai The Shared Values berhasil membentuk karakter

${ }^{13}$ Singapore Parliament. Parliamentary debates: Official report. (1991, January 14). Shared values (Vol. 56). Singapore: [s.n.], col. 839. (Call no.: RSING 328.5957 SIN) masyarakat

Singapura

untuk mengutamakan kepentingan bangsa dan negara dibanding kepentingan individu. Hal ini menciptakan keteraturan sosial dalam kehidupan bermasyarakat dan kehidupan politik. Contohnya, untuk naik taksi, orang-orang harus mengantre terlebih dahulu. Lebih dari itu, dalam kehidupan berpolitik, mengutamakan kepentingan negara menjadi hal penting yang mendukung kemajuan sebuah negara. Salah satu contohnya dapat terlihat dari minimnya korupsi di Singapura. Singapura menjadi negara ke-5 yang minim korupsi berdasarkan data Transparency International (TI) ${ }^{14}$. Ketika seseorang, khususnya politisi, menyadari bahwa kepentingan negara harus dijunjung, maka ia akan berusaha untuk memajukan negaranya dan mengesampingkan kepentingan diri sendiri.

Kemajuan politik dan sosial Singapura dapat pula ditinjau dari nilai-nilai Konfusianisme yang tidak tercantum dalam The Shared Values. Pertama, Singapura menjunjung meritokrasi ${ }^{15}$, yaitu sebuah sistem yang mengatur bahwa pemimpin dipilih berdasarkan kemampuan intelektualnya dan bukan berdasarkan

\footnotetext{
${ }^{14}$ Singapore Ministry of Foreign Affairs, 2012, https://www.mfa.gov.sg/content/mfa/index.htm 1, diakses 02 Agustus 2017, pukul 05.00 WIB ${ }^{15}$ Ibid
} 
kekayaan, silsilah keluarga, dan status sosial. Meritokrasi memainkan peran penting dalam kemajuan sebuah negara karena kekuasaan negara dipegang oleh orang yang benar-benar kompeten di bidangnya. Maka, sistem meritokrasi ini tidak mendiskriminasi komunitas atau golongan tertentu. Prinsipnya sama, yaitu semua ditujukan untuk kepentingan bangsa dan negara, sehingga tidak ada diskriminasi dalam pemerintahan dan bidang-bidang pekerjaan lainnya. Kedua, adanya hormat pada kewenangan pemerintah. Singapura tergolong negara yang otoriter, tetapi sebenarnya keotoriteran pemerintahan ini dibutuhkan untuk menciptakan keteraturan sosial. Kewenangan menunjukkan adanya hierarki antara pemerintah dan masyarakat sehingga masyarakat harus menaati pihak yang memiliki kewenangan dan kedudukan lebih tinggi, yaitu pemerintah. Pemerintah tidak menyalahgunakan kewenangan untuk ditaati karena berpegang pada prinsip menjunjung kepentingan bangsa dan negara. Hal ini juga sesuai dengan prinsip Yì (kebenaran dan keadilan). Ketiga, Singapura menjunjung prinsip Zhì (pengetahuan) dengan upayanya memberikan pendidikan yang terbaik bagi setiap warga negaranya. Selain diberi pendidikan moral, Singapura juga menekankan pada pentingnya pendidikan kognitif dengan penyusunan silabus pembelajaran yang berbasis bakat individu. Keempat, pendidikan di Singapura didukung dengan kedisiplinan, seperti prinsip self-discipline yang diajarkan pada Konfusianisme. Penanaman nilai kedisiplinan penting karena anak-anak yang bertumbuh dengan nilai kedisiplinan dapat menggunakan waktu dengan baik dan nilai kedisiplinan ini akan mereka bawa sebagai bekal mereka ketika memasuki dunia kerja. Kedisiplinan mencerminkan etos kerja yang baik sehingga hasil kerjanya juga akan maksimal.

\section{E. Kesimpulan}

Konsep Konfusianisme yang dimaksud adalah etik Konfusianisme dan konsep di empat penjuru samudera adalah saudara yang mendukung dari karakter nasional dan konsep lima hubungan manusia/five human relationship yang mendukung dari kualitas pemerintahan Singapura.Asumsi bahwa nilai Asia tergerus dengan nilai Barat tidak terbukti di Singapura. Konfusianisme yang diekstrak menjadi The Shared Values berkembang, menjadi identitas nasional dan menjadi dasar bagi kehidupan bernegara dan bermasyarakat di Singapura. Peran Konfusianisme vital dalam kemajuan politik Singapura karena satu hal 
yang utama, yaitu menjunjung kepentingan bangsa dan negara. Ketika kepentingan bangsa dan negara diletakkan sebagai prioritas, masyarakat merasa sebagai satu kesatuan yang berjuang untuk menjaga persatuan nasional, menjaga keharmonisan, dan memajukan aspekaspek kehidupan negara.

Perkembangan Konfusianisme Implementasi ajaran Konfusius telah memberikan sumbangan positif bagi pertumbuhan ekonomi yang cepat dalam rangka proses modernisasi di Singapura. Secara garis besar, ajaran Konfusius yang diimplementasikan dalam kehidupan sosial di Singapura telah menopang terjadinya pertumbuhan ekonomi Singapura yang cepat. Ajaran Konfusius yang dilihat sebagai faktor pertumbuhan ekonomi yang cepat di Singapura adalah ajaran mengenai kepatuhan dan kesetiaan, pemahaman bahwa negara adalah agen moral yang aktif dalam pembangunan masyarakat, penghormatan atas status dan hierarki, penekanan pada pengembangan diri dan pendidikan, dan perhatian terhadap harmoni sosial. Berkembangya waktu dan modernisasi, ideologi konfusiansme mengalami perkembangan menjadi neo konfusianisme. Neo konfusiaisme merupakan penggabungan antara nilai-nilai konfusianisme, Daoisme dan Budhisme.
Yaitu dimana konfusianisme mengajarkn penyelaraskan hubungan antar manusia, Daoisme memberikan nilai perlunya hubungan manusia dengan alam, serta Budhisme yang menganjurkan penyelarasan hubungan antara manusia dengan sang pencipta.

Peran Konfusianisme di Singapura dipetakan ke dalam tiga konsep, yaitu Pertama, Etik Konfusianisme Dalam etnik Konfusianisme, ajaran yang paling mendalam dari Kŏngzǐ dengan demikian terletak pada tekanannya untuk membangun diri atau pemberadaban diri (self-cultivation), keteladanan moral serta kemampuan untuk membuat keputusan yang terlatih baik, ketimbang pengetahuan akan hukum-hukum alam. Refleksinya, konsep konfusianisme dalam etik konfusianisme adalah sikap-sikap pembenahan dan pembentukan kualitas diri. Seperti etos kerja yang giat, rajin dan serius tunduk terhadap otoritas yang lebih tinggi, menghormati orang tua, etos kerja yang giat, rajin dan serius, selalu mencari konsensus dan keharmonisan dan menekankan pada ketertiban dan stabilitas. Kedua, lima Hubungan Antar Manusia Sebuah konsep dari ajaran Konfusianisme yang mendukung dengan kualitas pemerintah Singapura (The Quality of Government) adalah konsep yang 
dinamakan five human relationships. Five

Human Relationships yaitu ajaran

Konfusianisme mengenai bagaimana

hubungan antara pemerintah dengan

rakyatnya yaitu bagaimana rakyat dalam

bersikat terhadap pemerintah serta bagaimana pemerintah bersikap terhadap rakyatnya. Ketiga, Empat Penjuru Samudera adalah Saudara. “...Jika engkau tekun, engkau akan memperoleh hasilnya“. Ketika etik konfusianisme fokus terhadap pengembangan diri manusia, dan lima hubungan antar manusia pada sistem sosial, kini empat penjuru samudera adalah saudara ini menerapkan kepada individu untuk melakukan segala hal dengan ketekunan dan memberikan bentuk nilai atau hasil. Konsep ini di kaitkan pada masyarakat konfusianisme untuk selalu tekun dan serius guna mencapai hasil kerja yang sempurna, termasuk dalam bidang bisnis sebagai pondasi keberhasilan Singapura dalam bidang ekonomi. 
ASIAN VALUES DI SINGAPURA

(STUDI TENTANG PERAN KONFUSIANISME

DALAM KEMAJUAN POLITIK SINGAPURA)

\section{DAFTAR PUSTAKA}

\section{Dari buku}

Buckingham, W., Burnham, D., King, P.J., Hill, C., Weeks, M., Marenborn, J. (2011). The Philosophy Book. New York, NY: DK Publishing.

Pye, L. (1996). Aspects of Political

Development: An Analytic Study. Boston, MA: Little Brown.

\section{Dari jurnal online}

Homfeldt, H.G. and Reutlinger, C. (2008). Social Development. Social Work and Society International Online Journal, 6(2). Retrieved from http://www.socwork.net/sws/article/v $\underline{\text { iew/70/372 }}$

\section{Dari artikel online}

Kaplan, R.D. (2015, February 6). Asia's Rise Is Rooted in Confucian Values. Wall Street Journal. Retrieved from http://www.wsj.com/articles/asiasrise-is-rooted-in-confucian-values$\underline{1423254759}$

Mahbubani, K. (2015, August 4). Why Singapore Is The World's Most Successful Society. Huffington Post.
Retrieved from

http://www.huffingtonpost.com/kish ore-mahbubani/singapore-worldsuccessful-society_b_7934988.html

Ministry of Foreign Affairs. (2012, December 6). Strait Times: Singapore Remains $5^{\text {th }}$ Least Corrupt Country. Retrieved from http://www.mfa.gov.sg/content/mfa/ media_centre/singapore_headlines/2 $\underline{\text { 012/201212/infocus_20121206.html }}$

Sim, W. (2015, November 8). The race issue: How far has Singapore Come?. Strait Times. Retrieved from http://www.straitstimes.com/politics/ the-race-issue-how-far-hassingapore-come

Singapore National Library Board. (2004, December 18). Shared Values.

Retrieved from http://eresources.nlb.gov.sg/infopedi a/articles/SIP 542_2004-12-18.html

Teenhankee, J.C. (2007). The Political Aftermath of the 1997 Crisis: from Asian Values to Asian Governance?. Retrieved from http://library.fes.de/pdf- 
files/bueros/singapur/04601/2007-

2/teehankee.pdf

Weiming, T. (2016). Confucianism.

Retrieved from

http://www.britannica.com/topic/Con

fucianism

Anon. t.t. Singapore. [Online] dalam

http://www.freedomhouse.org/report/f reedom-

world $/ 2007 /$ singapore page $=22 \&$ coun

try $=7269 \&$ year $=2007 \# . U z \operatorname{lPgGnxp4o}$

(diakses pada 30 Juli 2017)

Anon. 2014. KRI Usman-Harun,

Menhan: Namanya Tetangga, Pasti

Ada Konflik. [Online] dalam

http://nasional.news.viva.co.id/news/r

ead/480180-kri-usman-harun--

menhan--namanya-tetangga--pasti-

ada-konflik (diakses pada $30 \mathrm{Juli}$

2017).

Anon. t.t. Proposal to develop

Integrated Resorts - Ministerial

Statement by Prime Minister Lee

Hsien Loong. [Online] dalam

http://app.mti.gov.sg/data/pages/606/d

oc/Ministerial\%20Statement\%20-
\%20PM\%2018apr05.pdf (diakses

pada 30 Juli 2017).

Kearney, A.T. t.t. "Measuring

Globalization" dalam Foreign Policy.

[Online]

http://www.foreignpolicy.com/articles /2005/05/05/measuring_globalization (diakses pada 30 Juni 2017). 